\title{
Fire History Determination IN THE MiXed CONIFER/ASPEN COMMUNITY OF Bryce Canyon National Park
}

\author{
MICHAEL J. JENKINS $\downarrow$ DEPARTMENT OF FOREST RESOURCES \\ UTAH STATE UNIVERSITY $\bullet$ LOGAN
}

\section{INTRODUCTION}

The major objective of this ongoing study is to document vegetative changes resulting from alteration of the fire regime in the mixed conifer/aspen communities of Bryce Canyon National Park. Previous fire history studies have documented fire return intervals using fire scar analysis of ponderosa pine Pinus ponderosa in the park (Buchannan and Tolman 1983: Wight 1989) and for the Paunsaugunt Plateau (Stein 1988). Numerous other studies have similarly documented the fire regime in pre-European settlement ponderosa pine forests in western North America.

The study is being conducted in the more mesic mixed conifer communities at the south end of Bryce Canyon National Park and will specifically document vegetative changes suggested by Roberts et al. (1992) resulting from suppression of frequent low intensity surface fires and overgrazing.

\section{$\checkmark \quad$ METHODS}

Three areas in the mixed conifer/aspen community type were selected for this study based on the description by Roberts et al. 1992. These were Whiteman Bench, Bridge Hollow and Yovimpa Pass. Using maps and aerial photos, a transect was established to represent the variety of elevation, aspect and other features of each area. Ten 1/4 acre plots were selected on each of the three transects for sampling.
All trees in each plot were tallied by species and diameter and a subsample from each visible fire scars were marked and later sampled using the chain saw wedge technique described by Arno and Sneck (1977). Each sample tree was permanently labeled with a metal tag for maintenance in the NSP records. All samples were taken to the Fire Ecology Laboratory at USU for analysis.

\section{$\checkmark \quad$ RESUltS AND DISCUSSION}

The analysis of data to date yields the results shown in Figures 1-3. The graph compares numbers of trees by diameter class, species and location. Superimposed is the average age of each species in each diameter class. It is apparent from these data that numbers of the shade tolerant white fir Abies concolor and Douglas fir Pseudotsuga menziesii have become established in the last 100 years. The majority of older, larger trees are ponderosa pine which must have been the dominant species historically and are now being replaced.

Table 1 shows the mean fire return interval found from fire scar specimens collected. The return interval was constructed by counting the number of fires and dividing the number into the total number of years. This value represents the number of years between fires sufficiently intense to scar a tree in the study area. Clearly each fire varied in its ecological significance depending on its size and intensity. Conversely there were surely other fires during the time period that did not scar trees or where fire scars 
were not found in the present study. The main purpose of presenting these dates is to illustrate the frequency with which ignitions occurred even in the mesic mixed conifer type. The return interval can also be evaluated in comparison to the fact that only 2 fires were documented by fire scars since 1900 . These new data are supported by previous fire history studies. Buchannan and Tolman (1983) recorded 87 fires in the mixed conifer type from 1616 to 1900 and 6 fires since 1900. Their data suggested that a fire sufficient to scar a tree occurred in the mixed conifer type once every 3-5 years in the period before 1900 . Since that time the interval has been lengthened to 16 years with one fire in 1959 being the only recorded since 1928. In Stein's (1988) fire history of the Paunsaugunt Plateau, he determined a fire return interval of 15.2-18.4 years. The last recorded fires in his study occurred in 1892, 1902, and 1911.

Table 1. Fire frequency calculations for fire scarred trees for the period 1501-1900.

No. of

sample

trees

No. years Total fires Fire freq.

20

399

53

7.5 Years

It is clear that alteration of the fire return interval resulting from fire suppression and removal of fine fuels by grazing has altered vegetative composition in the mixed conifer type of Bryce Canyon National Park. The abundance of white fir and Douglas fir could not have occurred over such a wide area under a pattern of frequent, low intensity surface fires. There were areas where these species became established and survived to produce bark thick enough to withstand surface fires. This is indicated in Figure 1 by the presence of older individuals of White fir and Douglas fir. It is the abundance of these species present that reflect the consequences of an altered fire regime. These data support the conclusions of Roberts et al. (1992) that reduction in surface fire has altered community type structure reducing the area occupied by quaking aspen and ponderosa pine.

\section{- MANAGEMENT IMPLICATIONS}

This work will explicitly document the effects on vegetation resulting from alteration of the fire regime in the mesic sites which most quickly respond to change. The documentation of this change will allow NPS personnel to make recommendations involving fuel reduction around the residential area and visitor center in stands dominated by ponderosa pine. The challenge of conducting prescribed burns in the mixed conifer type is great. High fuel loads and steep dissected topography are common and fire intensity would likely be high.

The main work yet to be accomplished in this study is to interact with park resource and fire personnel to determine likely potential management scenarios based on the results of this study.

One week will be spent in the park in the summer of 1994 to collect data sufficient to write a final section to this report.

\section{- Literature Cited}

Arno, S.F. and K.M. Sneck. 1977. A method for determining fire history in coniferous forests of the Mountain West. U.S. For. Serv. Gen. Tech. Rep. INT-42. 28 pp.

Bucannan, H. and J.M. Tolman. 1983. Fire history of the forest of Bryce Canyon National Park, Utah. Final Report USDI Contract No. PX 1330-0-0161. 40 pp.

Roberts, D.W., D. Wight and G.P. Halsten. 1992. Plant community distribution and dynamics in Bryce Canyon National Park. Final Report USDI Contract No. PX 1200-7-0966. $203 \mathrm{pp}$.

Stein, S.J. 1988. Fire history of the Paunsaugunt Plateau in southern Utah. Great Basin Naturalist 48(1):58-63.

Wight, D.W. 1989. Fire history, residential study area, Bryce Canyon National Park. BCNP Resource Management Office Report. 33 pp. 


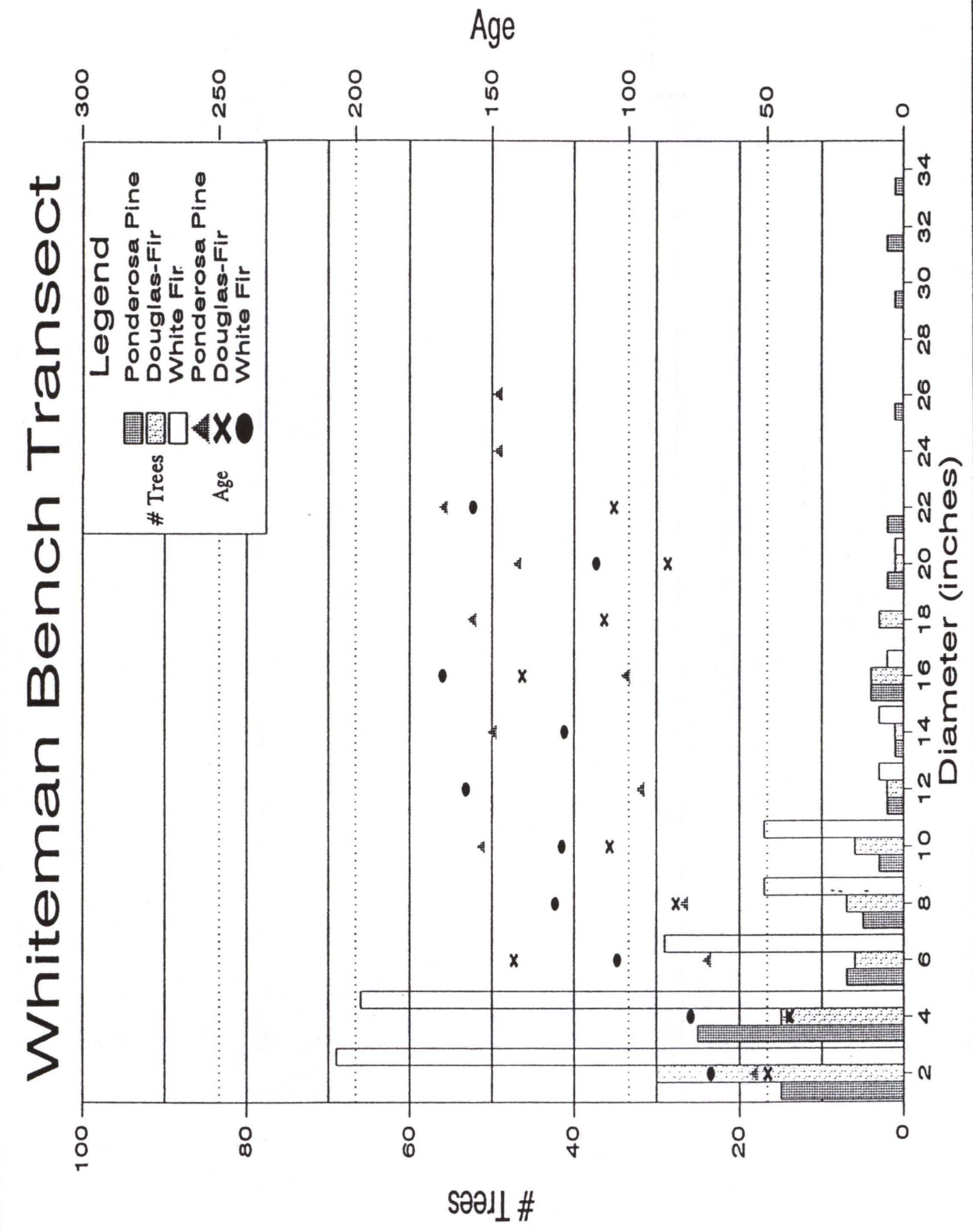




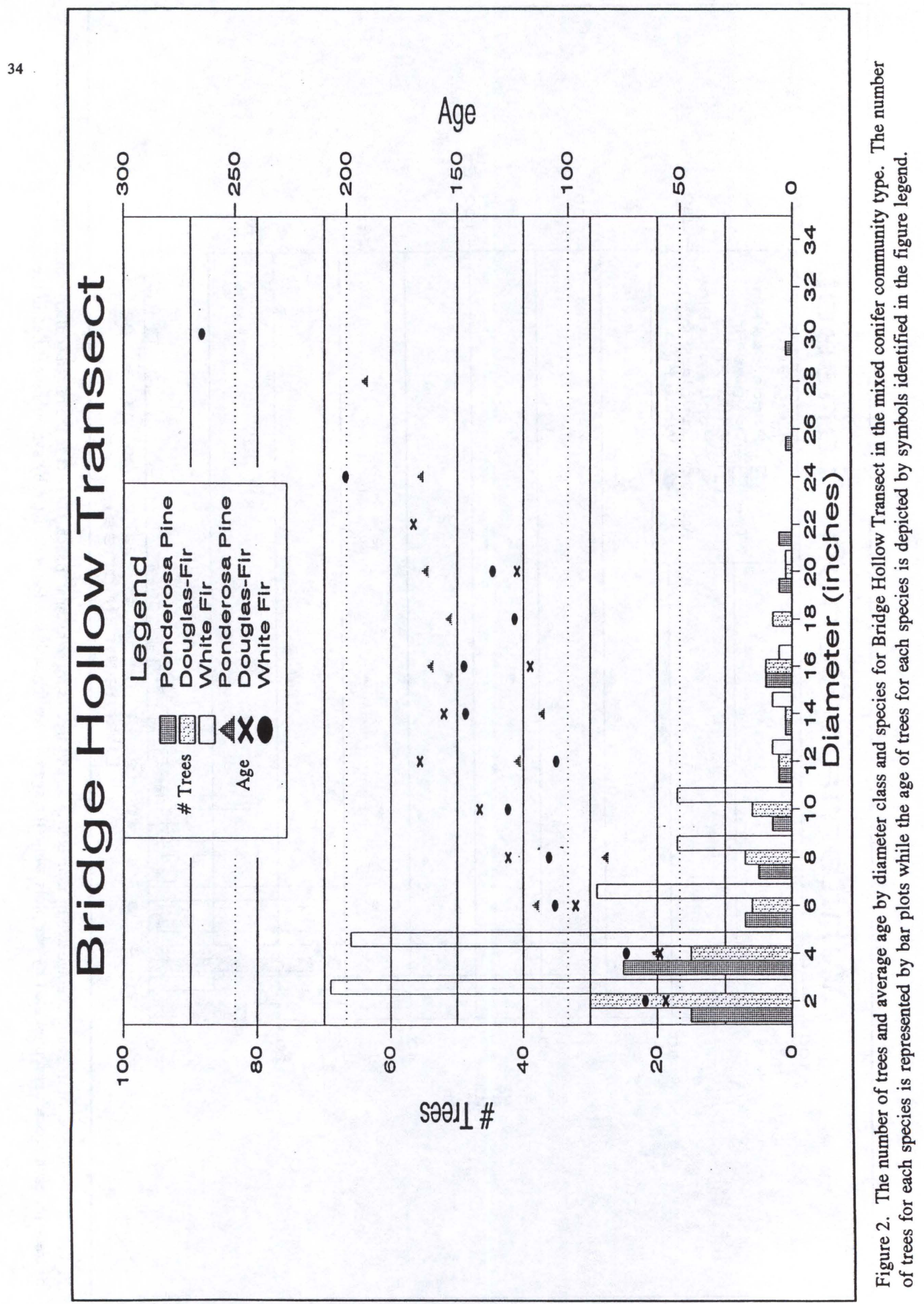




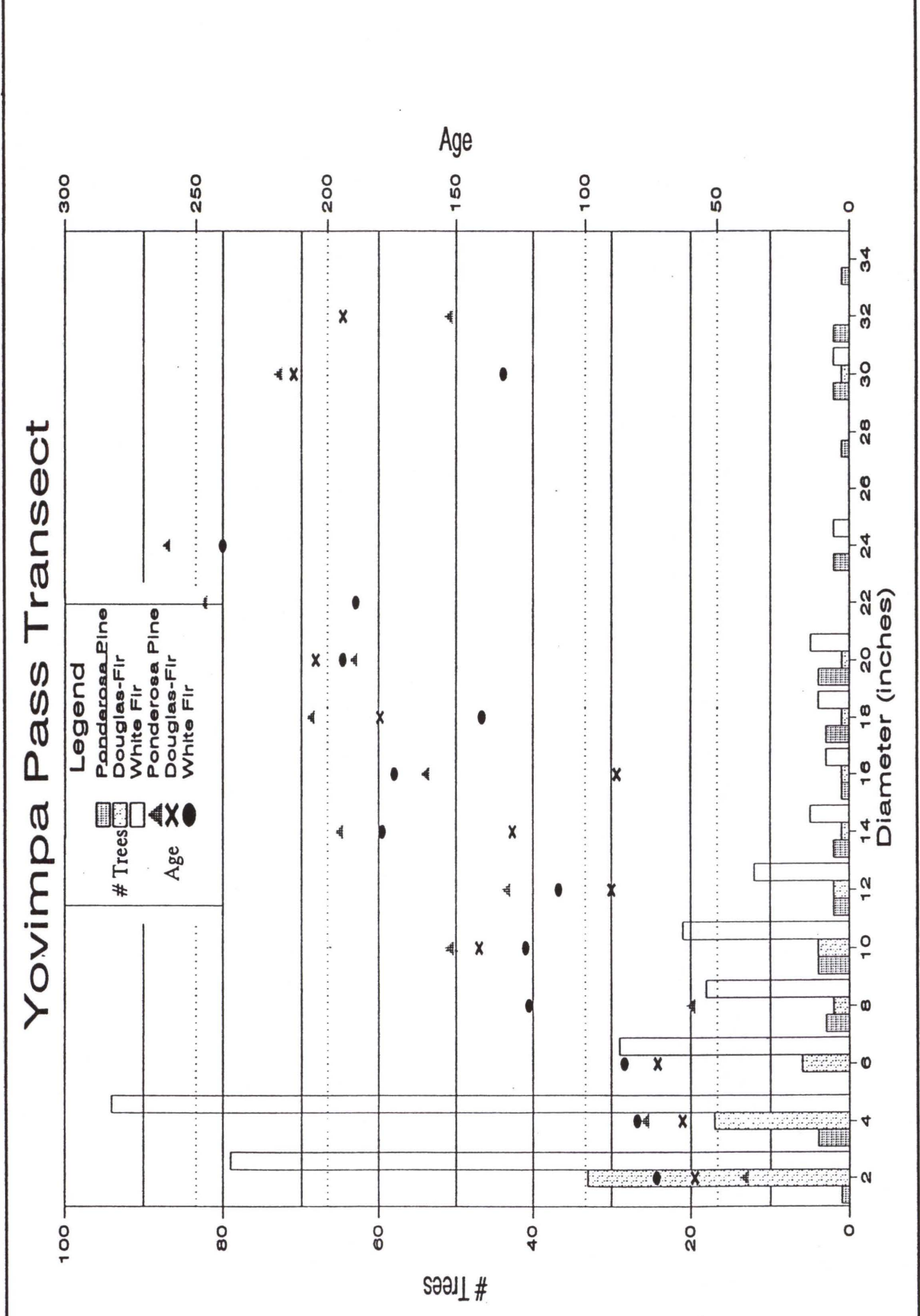

竜

35

i.

究路

률

要

잉

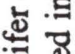

递密

赵

魚器

䓍

.

预

党

a

悬

흉

产

造

宊岩

瓷

馬

氙 :

즈윰

总

혼

¿

్ㅗㄹ

ఖั

茨

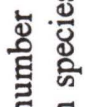

宛

Е

훙

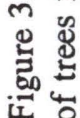

